\title{
The Intervening Effect of Global Financial Condition on the Determinants of Bank Performance: Evidence from Nigeria
}

\author{
James O. Alabede, FCA, FCTI, ACIB, PhD \\ Department of Accounting, Federal Polytechnic Bauchi, Nigeria \\ Tel: 234-81-3614-5549Ｅ-mail: joalabede@yahoo.com
}

Received: September 19, 2012

Accepted: October 26, 2012

Online Published: October 31, 2012

doi:10.5430/afr.v1n2p161

URL: http://dx.doi.org/10.5430/afr.v1n2p161

\begin{abstract}
The global financial crisis had devastating effect on both developed and developing economies. In Nigeria, the effect of the crisis swerve through the major sectors of the economy with the banking sector greatly affected. This study investigates the determinants of Nigerian banks' performance from 1999 to 2010 while taking into consideration the intervening effect of global financial condition. The data of the study, which were extracted from annual reports of the banks as well as various publications of Central Bank of Nigeria and Nigerian Deposit Insurance Corporation, were treated statistically using multiple regressions. The study provides evidence indicating that in the presence of the effect of global financial condition, only assets quality and market concentration are significant determinants of the Nigerian banks' performance. By implications, these findings suggest the need to keep nonperforming assets at minimum and introduce a policy to encourage fair competition among the banks operating in Nigeria in order to check concentration of banking services among only few banks.
\end{abstract}

Keywords: Bank performance, Global financial crisis, Banking sector

\section{Introduction}

The role of the financial system in mobilizing and channeling of funds to the real sectors of the economy cannot be taken for granted. Sound financial system is recognized as a necessary and sufficient condition for rapid growth and development for every modern economy (Ebong, 2005; Sanusi, 2012; Shonekan, 1997). Therefore, crisis in the financial system equally means crisis in the economy.

The financial system consists of institutions like banks, insurance, stock market etc. In Nigeria, the banking sector is an important part of the financial system. The banking sector dominates the Nigerian financial system as it accounts for about $90 \%$ of the total assets in the system and about $65 \%$ of market capitalization of the Nigeria Stock Exchange (Soludo, 2009a). However, the banking sector has not contributed significantly to the growth and development of Nigerian economy as expected. The poor performance of the sector has been attributed to numerous problems that faced the sector such as inadequate capital, high nonperforming assets etc which had led to frequent distress in the sector and collapse of some banks (Note 1) in the past (Obadan, 2004; Sanusi, 2012).

The problem in Nigerian banking sector was partly addressed by the reform introduced in the sector in 2004 by Central Bank of Nigeria $(\mathrm{CBN})$. As part of the 13 points reform, CBN reviewed the minimum capital of Nigerian banks to $\$ 25$ billion with effect from December 2005. This reform led to consolidation of banks hence the banks operating in Nigeria reduced to 25 from 89 in 2004 (CBN, 2006).

However, the gains from the 2004 bank reform did not last before the adverse effect of global financial crisis set in the sector. At the onset of the global meltdown, there was assurance that the Nigerian banking system would not be badly affected because of the sound capital base of the banks (Soludo, 2008). Nevertheless, Nigerian banks like banks in other countries had their share of the consequences of the global meltdown. Nigerian banks were adversely affected by the crisis as a result of their exposure to the capital market and oil sector. The total credit to share backed lending and oil related business stood at $\$ 900$ billion and $\$ 754$ billlion and these amounts represent $12 \%$ and $10 \%$ of aggregate credit respectively in 2008 (Sanusi, 2010a; 2012). In the wake of the global financial crisis, Nigerian Stock Exchange collapsed by about $70 \%$ and oil price dropped significantly (Sanusi, 2012). As direct consequence of the crisis, many Nigerian banks sustained losses from their operation and the capital adequacy rate dropped from $22 \%$ in 2008 to $10.24 \%$ in 2009 (Sanusi, 2010b; Nigerian Insurance Deposit Corporation (NIDC), 2010). The grave 
condition in the Nigerian banking Sector during the global financial crisis made the CBN to embark on a new reform to save the sector from total collapse.

This study was conducted primarily to ascertain the determinants of Nigerian banks' performance from 1999 to 2010 while taking into consideration the intervening effect of the global financial condition. As contribution to the banking literature, the study incorporated the effect of global financial condition to account for the global financial crisis and updated the literature on the determinants of Nigerian banks' performance. The findings from the investigation indicate that in the presence of effect of the global financial condition, only assets quality and market concentration are significant determinants of the Nigerian banks' performance. The remaining parts of this paper are organized as follows: in part 2, literature on development in Nigerian banking sector and determinants of banks' performance is reviewed. While in part 3 and 4, methodology as well as results and discussion are presented. In the final part, the conclusion and implications of the findings are discussed.

\section{Literature Review}

\subsection{Development in Nigerian Banking Sector from the Past to the Present}

The development of banking activities in Nigeria can be classified as free banking era, regulated banking era, deregulated banking era, consolidated banking era and post consolidated banking era (Nwankwo, 1980; Somoye, 2008). The free banking era also known as pre-independence banking period marked the genesis of the development of banking activities in Nigeria and the era was before 1952. Two main features characterized the era. The first feature was the absence of any banking legislation as anyone could establish a banking company as long as he registered under the Companies Ordinance 1948. The second feature of the era was that five banks were established consisting of three biggest foreign banks and two biggest indigenous banks (Nwankwo, 1980). However, Aigbiremole and Aigbiremolen (2004) reported that between 1947 and 1952, 22 banks were registered in Nigeria.

Banking operation actually started in Nigeria with establishment of African Banking Corporation (ABC) in 1892 and two years later, the Bank of British West Africa (BBWA) (now First Bank of Nigeria Plc) was established to take over ABC. BBWA remained the only bank operating in Nigeria until Barclays Bank (now Union Bank Plc) joined it in 1912. The third foreign bank to operate in Nigeria was British and French Bank Ltd (now UBA Plc) which was established in 1949. The first indigenous bank in Nigeria was the National Bank of Nigeria, which was established in 1933. The second successful indigenous bank was African Continental Bank Ltd, which started operation in 1947.

Following the collapse of some banks in the free banking era, it became obvious that there was need for legislation for the control of the Nigerian banking sector. As a result, the first banking legislation in Nigeria was passed in 1952. This marked the beginning of regulated era in the Nigerian banking sector. Under the 1952 Banking Ordinance, before a bank was allowed to operate in Nigeria, it must have a banking licence and must have a minimum paid up capital of $£ 25,000$ for indigenous bank and $£ 200,000$ for foreign bank.

In 1958, Central Bank of Nigeria (CBN) was established through CBN Ordinance of 1958 to supervise Nigerian banking sector and under 1958 Ordinance, the authorised capital of foreign banks was raised to $£ 400,000$. The Banking Ordinance of 1952 together with its several amendments was replaced with the Banking Decree of 1969. With the introduction of Structural Adjustment Programme (SAP) in 1986, the Nigeria banking sector was deregulated. As a result of the deregulation, the number of banks operating in Nigeria increased from 55 to 125 together with 275 branches of the people's bank and 1,000 community banks (CBN, 1998). During the deregulation era, Banking Decree of 1969 was repealed while Bank and Other Financial Institution Act of 1991 (BOFIA) was promulgated. The new Act raised the minimum capital of banks to $\$ 50$ million for commercial banks and $\$ 40$ million for merchant banks in 1991 and this was further increased to $\$ 2$ billion in 2001 (see Table1 ).

Insert Table 1 here

In 2004, CBN embarked on major reform in the Nigerian banking sector with a 13-point agenda and this marked the commencement of the consolidation era. The objective of the reform was to consolidate the Nigerian banks and increase their capital (Somoye, 2008). As part of the reform, the minimum capital for Nigerian banks was reviewed from $\$ 2$ billion to $\$ 25$ billion in July 2004 with effect from 31 December 2005. Before the consolidation era, 89 commercial banks were operating in Nigeria but the number reduced to 25 after consolidation (see Table2). Thought the 2004 reform brought about great improvement in the health and performance of the banking sector, the effects of the global financial crisis weaken the gain from the reform.

Insert Table 2 here 
The grave conditions in the Nigerian banking sector under the crisis provoked the post consolidation reform tagged "The Project Alpha Initiative" in 2009 (Sanusi, 2012). As part of the reform, CBN carried out special examination into operation of Nigerian banks with specific reference to the liquidity, capital adequacy and corporate governance in 2008. The results indicate that 10 of the 24 banks were in grave condition (Note 2). To save the sector, CBN removed and replaced chief executive and directors of 8 banks (Note 3) with more competent hands and bailed out 9 banks with $¥ 620$ billion public money (Sanusi, 2010b). In addition, in order to reduce the problem of liquidity in the sector, CBN promoted the establishment of Assets Management Corporation of Nigeria (AMCON) (Note 4) in 2010 to be acquiring nonperforming risk assets of the banks. Similarly, it also reviewed and replaced the universal banking model which was adopted in Nigeria in 2001 with a new model which make banks to focus on core banking business. Under the new model, banking licences are categorized into three: commercial banking (regional, national or international); merchant (investment) banking and specialized banking which could be microfinance (unit, state or national) mortgage (state or nation) or non-interest banking (CBN, 2011; Sanusi, 2010a).

In 2011, after 3 of the 8 banks bailed out with the public money failed to show commitment towards recapitalization, their banking licences were revoked and NDIC formed three new banks to take over their assets and liabilities (CBN, 2011) (Note 5). The remaining bailed banks were recapitalized through merger/acquisition and injection of refresh capital by core investors (Note 6). Subsequently, the number of deposit money banks (DMBs) operating in Nigeria reduced to 20 with 5,810 branches at end of 2011 (CBN, 2011). The various reforms in the Nigerian banking sector had impact on the performance of the sectors. The evidence on 2004 reform indicates that capital adequacy rate increased from $13.16 \%$ in 2004 to $21.25 \%$ in 2005 while liquidity improved from $50.44 \%$ to $60.69 \%$ and the ratio of nonperforming debt to total credit dropped from 23 to $20 \%$ in the same period (NIDC, 2005). Furthermore, because of the impact of the reform, all the 25 DMBs operating in Nigeria in 2005 were in sound condition (see table 3 ). The 2009 reform also shows great impact on performance of the banks and save the sector from collapse as a result of the adverse effect of the global financial crisis. Evidence available shows that the banks are recovering from the shock of the crisis as the number of DMBs in sound healthy condition increased from 13 in 2009 to 19 in 2011. This is reflected in the performance indicators: capital adequacy rate moved from $10.24 \%$ in 2009 to $17.9 \%$ in 2011 , liquidity increased from $44.17 \%$ to $69.1 \%$ and the ratio of nonperforming debt to total credit declined from 32.8 to $5 \%$ respectively (NDIC, 2010; CBN, 2011). However, this impressive performance was partly driven by the activity of AMCON. The AMCON took over $\$ 1.7$ trillion nonperforming risk assets of the DMBs in 2011 (Sanusi, 2012).

Insert Table 3 here

\subsection{Determinants of Bank Performance}

A number of studies in the banking literature have shown indicator of bank performance as return on assets (ROA) (Al-Tamimi, 2008; Beck, Cull \& Jerome, 2005; Berger, 1995; Flamini McDonald \& Schumacher, 2009; Naceur, 2005; Olweny \& Shipho, 2011). Furthermore, studies had been conducted to ascertain the determinants of bank performance in both developed and developing countries. Some of these studies were concentrated on the determinants of bank performance in a single country (Aburime, 2008, 2009; Al-Tamimi, 2008; Ayadi, Adebayo \& Omelehinwa, 1998; Beck, Cull \& Jerome, 2005; Naceur, 2003; Somoye, 2008; Wong, Fong, Wong \& Choi, 2007). Other studies on the determinants of bank performance were panel country studies (Athanasoglou, Delis \& Staikouras, 2006; Barros, Ferreira \& William, 2007; Demirguc-Kunt \& Huizinga, 1999; Flamini, McDonald \& Schumacher, 2009; Staikouras \& Wood, 2006).

In both single and panel country studies, empirical evidence suggests that bank performance is the function of both internal and external factors. The internal factors influencing the bank performance include bank specific characteristics like capital adequacy, operating expenses, liquidity, concentration etc. while external determinants include macroeconomic variables like financial structure, inflation rate, economic growth etc (Aburime, 2008, 2009; Al-Tamimi, 2008; Demirguc-Kunt \& Huizinga, 1999; Naceur, 2003).

For single country studies, Berger (1995) investigated a sample of banks operating from 1983 to 1992 in the US to determine the relationship between bank profitability and capital. The study reported positive association between bank performance and capital. In another study, Ayadi et al. (1998) revealed that bank performance monitoring indicators such as interest income, interest expenses, and total loan are weak in Nigeria in the period from 1990 to 1994. Naceur (2003) studied the determinants of profitability in the Tunisian banking industry from 1980 to 2000 and the author observed that variations in net interest margin and profitability were largely explained by specific bank characteristics like capital, large overhead etc. However, the study indicates that macroeconomic variables (inflation and GDP) did not have significant impact on bank performance. 
Furthermore, Beck et al. (2005) examined the effect of privatization on the performance of 69 Nigerian banks in 1990 to 2001. The finding of the study suggests that privatization had significantly improved the performance of Nigerian banks. Similarly, Al-Tamimi (2008) investigated factors influencing the performance of Islamic banks and conventional banks in United Arab Emirate (UAE) during the period of 1996 to 2008. The study provides evidence indicating that liquidity and concentration were significant determinants of conventional banks performance while cost and number of branches significantly influenced the performance of Islamic banks.

In other single country studies, Aburime (2009) examined the determinants of profitability of 33 Nigerian banks from 2000 to 2004 with particular reference on company level. The result shows capital size, credit portfolio and ownership concentration were significantly related to bank profitability. Other than that, Aburime (2008) also investigated the influence of macroeconomic variables on bank profitability using 154 Nigerian banks covering the period from 1980 to 2006 and observed that interest rate; inflation, monetary policy and exchange rate had significant impact on bank performance in Nigeria.

One of the early panel country investigation on determinants of bank performance was the study of Demirguc-Kunt and Huizinga (1999). The authors investigated the bank performance in the period of 1988 to 1995 in 80 countries and the result indicated differences in bank characteristics and macroeconomic variables as the determinants of net interest margin and bank profitability. In another panel country study, Grigorian and Manole (2002) investigated efficiency in commercial bank operations in transition countries in the period of 1995 to 1998. The study reported that foreign ownership and consolidation of banks enhanced commercial bank efficiency in transition countries. Similarly, Athanasoglou et al. (2006) examined profitability behaviour of banks operating in eastern European region from 1998 to 2002. The authors provided evidence, which indicated that all specific bank determinants influenced bank profitability significantly. However, the study did not find positive relationship between bank reform and bank profitability.

In other panel country studies, Staikouras and Wood (2006) reported that gross domestic product (GDP), interest, bank concentration, provision of loan loss and equity as significant determinants of bank profitability in 13 European countries in the period of 1994 to 1998. In the similar vein, the study of Barros et al. (2007) found country level characteristics like location and law as well as firm level features like bank ownership, balance structure and size to be important factors in the performance of 1384 banks in European Union between 1993 and 2001. Flamini et al. (2009) also observed that credit risk, bank size and macroeconomic variables are significantly associated with bank performance in the investigation of banks profitability in 41 sub-Saharan African (SSA) countries for the period of 1998 to 2006.

\subsection{Conceptual Framework}

Based on the literature presented on the determinants of bank performance in the preceding section, the relationship between independent and dependent variables of this study is depicted in the framework in figure 1 . The study incorporates specific bank variables, market structure variable and macroeconomic variables into a single model. The specific-bank, market structure and macroeconomic variables are internal and external factors that affect bank performance (Aburime, 2008, 2009; Al-Tamimi, 2008; Naceur, 2003). For the specific bank variables, the study only incorporated CAMEL which are factors used by CBN to assess the performance of Nigerian banks (CBN, 2008). Similar specific bank factors were also used in the study of Olweny and Shipho (2011). CAMEL framework, which represents Capital adequacy, Assets quality, Management efficiency, Earning performance and Liquidity, was developed by US Federal Deposit Insurance and recommended by Basle Committee on Banking Supervision and widely used as model for evaluating bank performance (CBN, 2004; Olweny \& Shipho, 2011). The market structure variable in the framework is bank concentration while the macroeconomic variables included gross domestic product (economic growth) and inflation.

\section{Insert Figure 1 here}

\subsection{Hypotheses}

With reference to the framework of this study and the literature generally reviewed on the determinants of bank performance, we propose the following hypotheses for validation:

$H_{l}$ : Ceteris paribus, bank capital adequacy is positively related to bank performance

$H_{l a}$ : Ceteris paribus, global financial condition intervenes in the relationship between bank capital adequacy and performance

$\mathrm{H}_{2}$ : Ceteris paribus, bank operating efficiency is positively related to bank performance 
$H_{2 a}$ : Ceteris paribus, global financial condition intervenes in the relationship between bank operating efficiency and performance

$H_{3}$ : Ceteris paribus, bank assets quality is positively related to bank performance

$H_{3 a}$ : Ceteris paribus, global financial condition intervenes in the relationship between bank assets quality and performance

$H_{4}$ : Ceteris paribus, bank liquidity level is positively related to bank performance

$H_{4 a}$ : Ceteris paribus, global financial condition intervenes in the relationship between bank liquidity and performance

$H_{5}$ : Ceteris paribus, bank concentration is positively related to bank performance

$H_{5 a}$ : Ceteris paribus, global financial condition intervenes in the relationship between bank concentration and performance

$H_{6}$ : Ceteris paribus, economic growth is positively related to bank performance

$H_{6 a}$ : Ceteris paribus, global financial condition intervenes in the relationship between economic growth and bank performance

$H_{7}$ : Ceteris paribus, inflation is positively related to bank performance

$H_{7 a}$ : Ceteris paribus, global financial condition intervenes in the relationship between inflation and bank performance

\section{Data and Methodology}

\subsection{Data Source}

This study used unbalanced data panel of 90 banks operating in the Nigerian banking sector between 1999 and 2010 . The data, which were derived from various publications of Central Bank of Nigeria, Nigerian Deposit Insurance Corporation and annual reports of banks, covered 476 observations. Two reasons were behind the choice of the period of this study. First, it was 1999 that Nigeria returned to democratic rule and since then the government has embarked on a number of reforms, which have impact on the operations of banks in Nigeria (Somoye, 2008). Second, it was between 2007 and 2010 that current financial crisis had severe impact on the world economy with serious consequence on the operation of banks (Crotty, 2009; Carmassi, Gros \& Micossi, 2009). The global financial crisis greatly affected banking operation in Nigeria just as banks in other parts of the world in this period (Adedipe, 2009; Berger \& Bouwman, 2009; Brambila-Macias \& Massa, 2010; Massa \& Velde, 2008; Naude, 2009; Soludo, 2008, Sanusi, 2010a).

\subsection{Variables Definition and Models Specification}

Most of the variables of this study were derived from the previous studies on bank performance. The operational definitions of these variables and their sources are summarized in Table 4. Two regression models were set out to achieve the objective of the study. In the first regression model, the ROA was used as indicator of bank performance and multiple regression analysis was carried out to determine the contribution of each independent variable in influencing ROA. In the second model, a mediating variable was incorporated to represent global financial condition and dummy variable was created with value of $(0)$ to represent period of stable global financial condition while value of (1) was used as proxy for period of global financial crisis. From the literature above, it is proposed that the global financial condition intervenes with the relationship between bank performance and its determinants. Based on the proposition, the second model was set for testing. The two regression models of the study are presented in the equation below.

$$
\begin{aligned}
& B R O A=\beta 0+\beta_{1} C A D+\beta_{2} B E F F+\beta_{3} B A S S Q+\beta_{4} B L I Q+\beta_{6} B C O N+\beta_{7} G D P+\beta_{8} I N F R+U . \\
& B R O A=\beta 0+\beta_{1} C A D+\beta_{2} B E F F+\beta_{3} B A S S Q+\beta_{4} B L I Q+\beta_{6} B C O N+\beta_{7} G D P+\beta_{8} I N F R+\beta_{9} F I N C+U \text {. }
\end{aligned}
$$

\section{Results and Discussion}

Insert Table 4 here

\subsection{Descriptive Statistics and Correlation Analysis}

The descriptive characteristics of Nigerian banks are presented in Table 5. The ROA was $2.1 \%$ in 1999 but dropped to $-9.28 \%$ in 2009 and increased to $3.91 \%$ in 2010 . As whole between 1999 and 2010 , the average ROA was $-2.55 \%$ and the standard deviation of 3.7. The results suggest that the Nigerian banks made negative returns on the average in this period. The ROA is negatively correlated with other variables expect for liquidity with which it is positively 
correlated. However, in all cases, it is the correlation between ROA and assets quality that is significant at 5\%. This suggests that quality of assets is important to bank performance (see Table 5).

Insert Table 5 here

Concerning Nigerian banks' capital, from 2003 the capital adequacy ratio was above the minimum standard of $10 \%$ but dropped to $4.32 \%$ in 2010 as a result of the impact of global financial crisis. However, the average capital adequacy ratio from 1999 to 2010 was a little above the minimum standard (10.71\%) with standard deviation of 5.0. Furthermore, the operating efficiency of the banks was $77.9 \%$ in 1999 but dropped to $72.44 \%$ in 2010 perhaps due to the effect of the global financial crisis. The mean score of the operating efficiency from 1999 to 2010 was 62.7 with standard deviation of 15 . However, the capital adequacy is not significantly correlated with other variables. In addition, the nonperforming assets (loan) of the Nigerian banks which was $20.82 \%$ in 1999 and deteriorated to $32.2 \%$ in 2009 as a result of the effect of global financial crisis, had mean score of 18.10 and standard of 7.9 for the period under review. Assets quality correlated positively with GDP and inflation while negatively with liquidity, concentration and global financial conditions although not at significant level.

Similarly, to reflect the impact of the banking reform, the liquidity of the banks increased from $50.9 \%$ in 1999 to $60.69 \%$ in 2005 . The effect of global financial crisis forced the liquidity to drop to $37.3 \%$ in 2008 but went up to $51.77 \%$ in 2010 following the impact of 2009 banking reform. However, the average liquidity ratio, which was $53.8 \%$ between 1999 and 2010, was above the minimum standard of 25\% set by CBN and has standard deviation of 11.6. Liquidity is not significantly correlated with other variables. For banks' concentration, $32 \%$ of the assets of the Nigerian banks was concentrated in the 3 largest banks in 1999 but it came down to $29 \%$ to reflect the impact of the banking reform and dropped further to $26.53 \%$ in 2010 and the average for the period from 1999 to 2010 was 27.7 together with 4.4 standard deviation. The correlation between bank concentration and other variables is negative but insignificant.

\subsection{Regression Analysis}

The regression results are documented in Table 6 and 7. Before the analysis, the data were tested for compliance with basic regression assumptions (multicollinearity, normality etc). The analysis indicates that model 1 has $\mathrm{F}$ ratio 8.731 $(\mathrm{P}=.027)$ and this suggests that the model has a significant ability to predict bank performance in Nigeria. The table also shows that model 1 has $\mathrm{R}^{2} .939$ which is an indication that the bank specific, market structure and macroeconomic variables combined together accounted for $93.9 \%$ of the variance of the dependent variable (ROA). However, a conservative estimate provided by the adjusted $\mathrm{R}^{2}$ indicates $83 \%$ of bank performance.

On the contribution of each variable as determinant of bank performance in model 1 , the regression result indicates that capital adequacy is negatively related to $\operatorname{ROA}(\beta=-0-.252 ; \mathrm{P}=0.241)$ but insignificant which suggests that the result fails to support hypothesis $\left(\mathrm{H}_{1}\right)$. This result is not expected but it is consistent with result of Flamini et al (2009) on banks in SSA and contrary to the findings of Aburime (2009), Athanasoglou et al. (2006), Berger (1995), and Naceur (2003) which reported that capital adequacy has positive impact on bank performance. This finding suggests that lower capital-to-asset produced higher bank performance. Perhaps the possible explanation for the result may be the deteriorating quality of capital of most Nigerian banks, for instance, in 2009, 10 of 24 banks operating in Nigeria recorded capital adequacy grossly below minimum requirement of $10 \%$ (NIDB, 2009). However, this result lends support from the argument of Flamini et al (2009) that lower capital tends to lead to higher bank performance.

Similarly, the operating efficiency is also significantly and negatively associated with bank performance ( $\beta=-0.352$; $\mathrm{P}<.10$ ). This result contradicts hypothesis $\left(\mathrm{H}_{2}\right)$ but agreed with the findings of Athanasoglou et al. (2006) and Olweny and Shipho (2011) on the South East European and Kenyan banks respectively. This suggests that Nigerian banks are not skillful in managing their operating expenses and equally illustrated that the inefficiency exhibited by most Nigerian banks in their operation had great impact on their performance. However, as indicated in descriptive analysis, the operating efficiency improved in 2009 in wake of the banking reform.

Furthermore, the assets quality significantly and negatively affected Nigerian banks' performance $(\beta=-0.902 ; \mathrm{P}<$ $0.05)$. This result is opposite the prediction in hypothesis $\left(\mathrm{H}_{3}\right)$. In the support of this finding, the study of Olweny and Shapiho (2011) also reported negative relationship between assets quality and performance of Kenyan banks but inconsistent with the result of Flamini et al (2009) which reported positive association between the two variables. This implies that increase in nonperforming assets will lead to low bank performance. The finding is not surprising considering the deteriorating nature of nonperforming assets as reported in the descriptive analysis, which was as high as $32.8 \%$ in 2009 . The concern for the deteriorating quality of Nigerian banks' assets made AMCON to acquire $\$ 1.7$ trillion toxic assets from the banks and this reduced the nonperformance assets to $15.5 \%$. 
In addition, the regression result indicates that bank liquidity is positively related to Nigerian bank performance $(\beta=$ $0.284 ; \mathrm{P}>0.10$ ). The finding suggests that higher banks' liquidity leads to better performance because with increased liquidity, banks would be able pursue more productive investment, which would boost their return. However, the result is reported at insignificant level as a result, it does not support hypothesis $\left(\mathrm{H}_{4}\right)$. Though the finding on the relationship between liquidity and bank performance is insignificant, it came as expected because as documented in Table 5, the liquidity position of Nigerian banks had not been so bad with an average of about $54 \%$ between 1999 and 2010. The findings of Al-Tamimi, (2008), Athanasoglou et al. (2006) and Olweny and Shipho (2011) on liquidity are similar to the result reported in this study.

Concerning the relationship between bank concentration and performance, the regression indicates significant negative association between the two variables $(\beta=-0.600 ; \mathrm{P}<0.05)$ and contradicts hypothesis $\left(\mathrm{H}_{5}\right)$. The interpretation to this result is that the higher the concentration of the provision of banking service in few firms the lower the bank performance. In Nigeria as reported in descriptive analysis, the three largest banks accounted for 32\% of the industry's assets in 1999 and this went up to $39 \%$ in 2006 before the global financial crisis and the 2009 banking reform. This suggests that banking service is highly concentrated; hence, this result is not surprising. Olweny and Shipho (2011) also reported negative association between bank concentration and performance but on the contrary, Aburime (2009), Athanasoglou et al. (2006), Staikouras and Wood (2006) established positive correlation between the two variables.

With regard to the macroeconomic variables, the results reveal that GDP is negatively related to bank performance but such relationship is insignificant $(\beta=-0.312 ; \mathrm{P}>0.10)$ and does not support hypothesis $\left(\mathrm{H}_{6}\right)$. This implies that increase in economic growth lower bank performance. The possible reason for this finding may be the rapid economic growth from $0.9 \%$ in 1999 to $10.2 \%$ in 2004 , which encouraged more firms to enter Nigerian banking industry such that there were 89 banks before 2004 banking reform, which increased competition, hence lower profit margin in the industry. However, on the contrary, the studies of Demirguc-Kunt and Huizinga (1999) and Flamini et al. (2009) found positive correlation between GDP and bank performance. Furthermore, the results disclose that association between inflation and bank performance is positive and significant $(\beta=0.400 ; \mathrm{P}<0.10)$ as expected and this supports hypothesis $\left(\mathrm{H}_{7}\right)$. The result is consistent with the findings reported in Aburime (2009), Athanasoglou et al. (2006) Demirguc-Kunt and Huizinga (1999) and Flamini et al. (2009). This suggests that as inflation increases, bank profit increases more than cost.

\section{Insert Table 6 here}

In model 2, the intervening effect of global financial condition was incorporated in the regression and result reveals (see Table 7) that in presence of the effect of global financial condition, the model is statistically fit (F ratio 5.792; $\mathrm{P}=.088$ ) to predict bank performance in Nigeria using ROA as dependent variable. The combined bank specific, market structure and macroeconomic variables together gave $\mathrm{R}^{2} 0.939$ and this provided $94 \%$ explanation of the determinants of bank performance in Nigeria. Conservatively, the model 2 provided about $78 \%$ (adjusted $\mathrm{R}^{2}$ ) account of the variance of the dependent variable. However, the relationship between global financial condition and bank performance is negative as expected but insignificant $(\beta=-0 . .50 ; \mathrm{P}>0.10)$. The banking reform undertaken by CBN provides possible explanation for why the global financial condition did not affect the bank performance greatly as expected.

On the contribution of each variables as the determinants of bank performance in the presence of the effect of global financial condition, the association between capital adequacy and ROA remains negative and insignificant as in model $1(\beta=-0.246 ; \mathrm{P}>0.10)$ and therefore fails to support hypothesis $\left(\mathrm{H}_{1 \mathrm{a}}\right)$. This suggests that global financial condition did not intervene in the relationship between the two variables greatly. The reason for this result may be linked to the bank recapitalization exercise in 2004, as it strengthened the bank capital to contain the shock of the global financial crisis to some extent. Unlike in model 1, global financial condition mediated the association between operating efficiency and bank performance negatively but insignificantly $(\beta=-0.335 ; \mathrm{P}>0.10)$. Therefore, the result does not support hypothesis $\left(\mathrm{H}_{2 \mathrm{a}}\right)$. This suggests that the global financial condition caused Nigerian banks to improve their operating efficiency slightly.

Despite the effect of global financial condition, relationship between assets quality $(\beta=-0.919 ; \mathrm{P}<0.05)$, bank concentration $(\beta=-0 . .591 ; \mathrm{P}<0.10)$ and bank performance remains negative and significant as in model 1 and these results support hypothesis $\left(\mathrm{H}_{3 \mathrm{a}}\right)$ and $\left(\mathrm{H}_{4 \mathrm{a}}\right)$. Furthermore, the association between liquidity $(\beta=0.248 ; \mathrm{P}>0.10)$, inflation $(\beta=0$. .384; $\mathrm{P}>0.10)$ and bank performance remain positive as in model 1. However, the relationship between inflation and bank performance became insignificant unlike in model 1 hence the results do not support hypothesis $\left(\mathrm{H}_{5 \mathrm{a}}\right)$ and $\left(\mathrm{H}_{6 \mathrm{a}}\right)$. Perhaps the possible explanation for this result is the impact of global financial condition, 
which increased the operating cost of Nigerian banks and lowers the profit margin. Other than this, GDP is insignificantly and negatively correlated to bank performance $(\beta=-0.291 ; \mathrm{P}>0.10)$ even in the presence of mediating effect of global financial condition as a result fails to agree with prediction of hypothesis $\left(\mathrm{H}_{7 \mathrm{a}}\right)$.

Insert Table 7 here

\section{Conclusion and Implications}

This study investigates the determinants of Nigerian banks' performance from 1999 to 2010 and the intervening effects of global financial condition on the determinants. The determinants investigated by the study include specific bank variables, market structure variable and macroeconomics variables. The findings are mixed.

On the specific bank characteristics, the findings did not support capital adequacy and liquidity as determinants of Nigerian banks' performance but it indicated operating efficiency, assets quality and bank concentration as significant determinants of the performance. In other findings, the GDP did not strongly affect the banks' performance while inflation greatly influenced the performance. However, in the presence of effects of global financial condition, this study provides statistical evidence to indicate that capital adequacy, liquidity, operating efficiency; GDP and inflation are not significant determinants of Nigerian banks' performance while assets quality and concentration greatly affected the performance. These findings pose some practical implications for policy makers.

First, the finding on the negative relationship between bank assets quality and banks' performance suggests that better strategy must be adopted at bank level to improve credit administration and debt recovery in order to keep nonperforming assets at minimum and boost return at this time of the global financial crisis. Furthermore, at national level, CBN should introduce stringent measure to cope with abuses of credit process by bank management. Second, the CBN should introduce a policy to encourage fair competition among the 20 banks operating in Nigeria in order to check concentration of banking services among only few banks. Finally, at bank level, the bank management has to keep down their cost by cutting unnecessary overhead cost and closing down redundant branches to boost their overall operating efficiency. This study is associated with some limitations. The most obvious limitation of this study that is the data used are accounting data and these data may suffer from distortion due to manipulation and accounting assumption and estimates. Added to that, the study focused on only DMBs and did not include specialized banks (microfinance banks, mortgage banks etc). However, future researchers may want to consider investigating factors driving the performance of these specialized banks particular under the global financial condition.

\section{References}

Aburime, U. (2009). Determinants of bank profitablity: company level evidence from Nigeria. [Online] Available: http://www.ssrn.com/abstract=1231064 (September 3, 2011).

Aburime, U. (2008). Determinants of bank profitablity: macroeconomic evidence from Nigeria. [Online] Available: http://www.ssrn.com/abstract=110685 (September 3, 2011).

Adedipe, B. (2009). Impact of global financial meltdown on the Nigerian financial system and suggested way out. Being text of paper presented in workshop organized by CBN in Lagos.

Aigbiremolen, M. O. \& Aigbiremolen (2004). Marketing: banking services in Nigeria. Lagos: Chartered Institute of Bankers of Nigeria (CIBN).

Al-Tamimi, H.A. (2010). Factors influencing performance of UAE Islamic and national conventional banks. Global Journal Business Research. 4(2),1-7.

Ayadi, O. F., Adebayo, A. O. \& Omolehinwa E. (1998). Bank performance measurement in a developing economy:

An application of data envelopment analysis. Managerial Finance. 24(7), 5-16. http://dx.doi.org/10.1108/03074359810765589

Athanasoglou, P., Delis, M., \& Staikouras, C. (2006). Determinants of bank profitablity in south eastern European region. [Online] Available: http://www.mpra.ub.uni_muenchen.de/10274 (August 26, 2011).

Barros, C., Ferreira, C., \& William, J. (2007). Analysing the determinants of performance of best and worst European banks: a mixed logit approach. Journal of Banking and Finance. 31, 2189-2203. http://dx.doi.org/10.1016/j.jbankfin.2006.11.010

Beck, T., Cull, R., \& Jerome, A. (2005). Bank privatisation and performance: empirical evidence from Nigeria. Washington CD: Working paper 3511, World Bank. http://dx.doi.org/10.1596/1813-9450-3511 
Berger, A. (1995). The relationship between capital and earnings in banking . Journal of Money, Credit and Banking. 27(2),432-456. http://dx.doi.org/10.2307/2077877

Berger, A., \& Bouwman, C. (2009). Bank capital, survival and performance around financial crisis. CREI/JFI/CEPR conference on financial crisis. Pompeu Fabra.

Brambila-Macias, J., \& Massa, I. (2010). The global financial crisis and sub-saharan Africa: the effects of slowing private capital inflows on growth. African Development Reviews. 22(3), 366-377. http://dx.doi.org/10.1111/j.1467-8268.2010.00251.x

Carmassi, J., Gros, D., \& Micossi, S. (2009). The global financial crisis: causes and cures. Journal of Common Market Studies. 47 (5), 977-996. http://dx.doi.org/10.1111/j.1468-5965.2009.02031.x

Central Bank Nigeria. (1994). Annual report and statement of account. Abuja: CBN.

Central Bank Nigeria. (2006). Annual report and statement of account. Abuja: CBN.

Central Bank Nigeria. (2009). Annual report and statement of account. Abuja: CBN.

Central Bank Nigeria. (2010). Annual report and statement of account. Abuja: CBN.

Central Bank Nigeria. (2011). Annual report and statement of account. Abuja: CBN.

Central Bank Nigeria. (2005). Banking supervision annual report. Abuja: CBN

Central Bank Nigeria. (2008). Banking supervision annual report. Abuja: CBN .

Crotty, J. (2009). Structural causes of global financial crisis: a critical assessment of the "new financial architecture". Cambridge Journal of Economics. 33, 563-580. http://dx.doi.org/10.1093/cje/bep023

Demirguc-Kunt, A., \& Huizinga, H. (1999). Determinants of commercial bank interst margin and profitability: some international evidence. The World Bank Economic Reviews. 13(2), 54-60. http://dx.doi.org/10.1093/wber/13.2.379

Ebong, B. B. (2005). The banking industry and the Nigerian economy: Post consolidation. Union Digest. 9 (3),17-30.

Flamini, V., McDonald, C., \& Schumacher, L. (2009). The determinants of commmercial bank profitablity in sub-saharan Africa. [Online] Available: http://www.inf.org/external/pubs/ft/wp/2009/w0915 (August 25, 2011).

Grigorian, D., \& Manole, V. (2002). Determinants of commercial bank performance in transistion: an application of data envelopment analysis. Washington DC: Working paper 2850, World Bank. http://dx.doi.org/10.1596/1813-9450-2850

Massa, I., \& Velde, D. (2008). The global financial crisis: will successful African countries be affected? Oversea Develoment Institute.

Naceur, S. (2003). The determinants of Tunisian banking industry profitablity: panel evidence paper. [Online] Available: http://www.academicdb.com/risk (August 15, 2011).

Naude, W. (2009). The financial crisis of 2008 and the develoing countries. [Online] Available: http://www.wider.unu.edu (August 25, 2011).

Nigeria Deposit Insurance Corporation. (2006). Annual report and statement of accounts. Abuja: NIDC

Nigeria Deposit Insurance Corporation. (2009). Annual report and statement of accounts. Abuja: NIDC

Nigeria Deposit Insurance Corporation. (2010). Annual report and statement of accounts. Abuja: NIDC

Nwankwo, G. O. (1980). The Nigerian financial system. London: MacMillan Publisher Ltd.

Obadan, M. (2004). Mergers and acquisition and the new minimum capital. Financial Standard, September 6, P 34.

Olweny, T., \& Shipho, T. (2011). Effects of banking sectoral factors on the profitablity of commercial banks in Kenyan. Economics and Finance Review, 1 (5), 1-30.

Onoh, J. K. (1993). From indigenous monetary system to indigenous banking: study of transition to a monetary economy in Irukwo, J. O. Nwonia, C. S. and Anunoby, O. C, Banking Development in Nigeria and the African Continental Bank ed; Lagos: Malthouse Press Ltd.

Sanusi, L. (2012a). Banking reform and its impact on the Nigerian economy. Lecture presented at the University of Warwick's Economic Summit, UK, Feburary, 17.

Sanusi, L. (2010a). Consolidating the gain of the banking sector reform. Asaba: lecture to the Sylvester Monye Foundation, Asaba, July,9. 
Sanusi, L. (2010b). Global financial meltdown and the reforms in the Nigerian banking sector. Lecture delivered at Abubakar Tafawa Balewa University, Bauchi, December, 10.

Shonekan, E.A (1997). The relevance of financial sector to Vision 2010. The Nigerian Banker. 1, 17.

Soludo, C.C. (2008). Global financial crisis and assurance by Yar Adua'a men. Nigeria Punch. $26^{\text {th }}$ October.

Soludo, C.C. (2009a). The developments in the banking sector. Being press released by Central Bank of Nigeria on $23 \mathrm{Feb}$.

Soludo, C.C. (2009b). Banking in Nigeria at a time of global financial crisis. Being text of paper presented at the special interactive session on the Banking system in Lagos.

Somoye, R. O. C. (2008). The performance of commercial banks in post-consolidation period in Nigeria: An Empirical Review. European Journal of Economic, Finance and Administrative sciences. 14(2), 62-73.

Staikouras, C., \& Wood, G. (2006). The determinants of European bank profitablity. International Business and Economic Research Journal. 3(6), 57-68.

Wong, J., Fong, T., Wong, E., \& Choi, K. (2007). Determinants of ther performance of banks in Hong Kong. Hong Kong: Working paper 06/2007, Hong Kong Monetary Authority.

\section{Notes}

Note 1. Number of distressed banks increased from 9 in 1990 to 60 in 1995 but dropped to 47 in 1997 (Obadan, 2004).

Note 2. The 10 banks in grave condition included Afribank, Equatorial Trust Bank, FinBank, Intercontinental Bank, Oceanic International Bank, Platinum-Habib Bank, Spring Bank, Sterling Bank, Union Bank, Unity Bank and Wema Bank.

Note 3. The chief executive officers removed from office were that of Afribank, Equatorial Trust Bank, FinBank, Intercontinental Bank, Oceanic International Bank, Platinum-Habib Bank, Spring Bank, Sterling Bank and Union Bank.

Note 4. AMCON acquired 1.7 trillion nonperforming assets of some Nigerian banks in 2011 (Sanusi, 2012).

Note 5. The 3 banks that failed to recapitalize before the CBN dateline were Afribank, Platinum-Habib Bank and Spring Bank and the Main Street Bank Ltd, Keystone Bank Ltd and Enterprise Bank Ltd were new banks established to take up their operations respectively.

Note 6. Equatorial Trust Bank, FinBank, Intercontinental Bank and Oceanic International Bank entered into merger/ acquisition agreement with Access Bank, Eco Bank, FCMB and Sterling Bank respectively. 
Table 1. Minimum capital in Nigerian Banking Sector from 1952-2011

\begin{tabular}{|c|c|c|c|}
\hline Minimum Capital & Year & Bank & Cumulative No of bank \\
\hline$£ 200,000$ & & Foreign & \\
\hline$£ 25,000$ & $1952-1978$ & Indigenous & \\
\hline$£ 400,000$ & & Foreign & 45 \\
\hline$£ 25,000$ & & Indigenous & \\
\hline $\mathrm{N} 1,500,000$ & & Foreign & \\
\hline $\mathrm{N} 600,000$ & & Indigenous & \\
\hline $\mathrm{N} 1,500,00$ & & Foreign & \\
\hline $\mathrm{N} 600,00$ & 1979-1987 & Indigenous & 54 \\
\hline N 2,000,000 & & Merchant bank & \\
\hline N 5 million & & Comm. Bank & \\
\hline N 3 million & 1988, Feb & Merchant Bank & 66 \\
\hline N 10 million & 1988 Oct. & Comm. Bank & \\
\hline N 6 million & & Merchant Bank & 66 \\
\hline N 20 million & & Comm. Bank & 107 \\
\hline N 120 million & $1989-1990$ & Merchant Bank & \\
\hline N 50 million & $1997-2001$ & Comm. Bank & 112 \\
\hline N 40 million & & Merchant Bank & \\
\hline N 500 million & $1997-2001$ & Comm. Bank & 110 \\
\hline N 500 million & & Merchant Bank & \\
\hline N 2 billion & $2002-2004$ & Universal Banking & 89 \\
\hline \multirow[t]{2}{*}{ N25 billion } & 2005-2008 & Universal Banking & 25 \\
\hline & 2009 & Commercial Banking: & \\
\hline N50billion & & International Authority & \\
\hline N25billion & & National Authority & 20 \\
\hline N10billion & & Regional Authority & \\
\hline \multirow[t]{2}{*}{ N15billion } & & Merchant Banking & \\
\hline & & Micro Banking: & \\
\hline N2billion & & National Microfinance & 821 \\
\hline N100million & & Stale Microfinance & \\
\hline \multirow[t]{2}{*}{ N20million } & & Unit Microfinance & \\
\hline & & Mortgage Banking: & \\
\hline N5billion & & National Mortgage & \\
\hline N2.5billion & & State Mortgage & \\
\hline N10billion & & Specialised Banking: & \\
\hline N5billion & & National non-interest bank & \\
\hline N5billion & & Primary non-interest bank & \\
\hline & & Regional non-interest bank & \\
\hline
\end{tabular}

Source: Central Bank Nigeria (2010). Annual report and statement of account.

Somoye, (2008). The performance of commercial banks in post-consolidation period in Nigeria: an empirical review 
Table 2. Consolidation Banks in Nigeria

\begin{tabular}{|c|c|c|}
\hline $\mathrm{S} / \mathrm{N}$ & Banks & Members of the Group \\
\hline \multicolumn{3}{|c|}{2005 Banks Consolidation } \\
\hline 1 & Access Bank Plc & Marina International Bank, Capital International Bank, Access Bank \\
\hline 2 & Afribank Plc & Afribank Plc, Afribank International Ltd (Merchant Banks) \\
\hline 3 & Diamond Bank Plc & Diamond Bank, Lion Bank, African International Bank (AIB) \\
\hline 4 & Eco Bank Plc & Ecobank \\
\hline 5 & Equatorial Trust Bank Plc & Equatorial Trust Bank, Devcom Bank \\
\hline 6 & FCMB Plc & $\begin{array}{l}\text { FCMB, Co-operative Developt Bank, Nigerian-American Banks, Midas } \\
\text { Bank }\end{array}$ \\
\hline 7 & Fidelity Bank Plc & Fidelity Bank, FSB International Bank, Manny Bank \\
\hline 8 & First Bank Plc & First Bank of Nigeria Plc, FBN Merchant Bank, MBC \\
\hline 9 & First Inland Bank Plc & IMB Bank, Inland Bank, First Atlantic Bank, NUB Bank \\
\hline 10 & Guaranty Trust Bank Plc & GT Bank Plc \\
\hline 11 & IBTC/Chartered Bank Plc & Regent Bank, Chartered Bank, IBTC \\
\hline 12 & Intercontinental Bank Plc & Global Bank, Equity Bank, Gateway Bank, Intercontinental Bank \\
\hline 13 & Nigerian International Bank & Nigerian International Bank \\
\hline 14 & Oceanic Bank Plc & Oceanic Bank, International Trust Bank \\
\hline 15 & Platinum-Habib Bank Plc & Platinum Bank, Habib Bank \\
\hline 16 & Skye Bank Plc & Prudent Bank, Bond Bank, Coop Bank, Reliance Bank, EIB Bank \\
\hline 17 & Spring Bank Plc & $\begin{array}{l}\text { Guardian Express Bank, Citizen Bank, Fountain Trust Bank, Omega } \\
\text { Bank, Tran-International Bank, ABC }\end{array}$ \\
\hline 18 & Stanbic Bank Plc & Stanbic Bank \\
\hline 19 & Standard Chartered Bank Ltd & Standard Chartered Bank Ltd \\
\hline 20 & Sterling Bank Plc & $\begin{array}{l}\text { Magnum Trust Bank, NBM Bank, NAL Bank, INMB Bank, Trust Bank } \\
\text { of African Ltd }\end{array}$ \\
\hline 21 & United Bank of Africa Plc & Standard Trust Bank, UBA, Continental Trust Bank \\
\hline 22 & Union Bank Plc & Union Bank, Union Merchant Bank, Universal Trust Bank, Broad Bank \\
\hline 23 & Unity Bank Plc & $\begin{array}{l}\text { New Africa Bank, Tropical Commercial Bank, Central-Point Bank, Bank } \\
\text { of North, New Nigeria Bank, First Interstate Bank, Intercity Bank, } \\
\text { Societe Bancaire, Pacific Bank, }\end{array}$ \\
\hline 24 & Wema Bank Plc & Wema Bank, National Bank \\
\hline 25 & Zenith International Bank Plc & Zenith International Bank Plc \\
\hline
\end{tabular}

2011 Banks Consolidation

$1 \quad$ Access Bank P

2 Diamond Bank Plc

$3 \quad$ Eco Bank Plc

4 Enterprise Bank Ltd (former

Spring Bank Plc)

$5 \quad$ First City Monument Bank Plc

$6 \quad$ Fidelity Bank Plc

Intercontinental Bank Plc

Oceanic Bank Plc

FinBank 
7

8

9

10

11

12

13

14

15

16

17

18

19

20

First Bank Plc

Guaranty Trust Bank Plc

Keystone Bank Ltd ( former

Bank PHB Plc)

Nigerian International Bank

Main Street Bank Ltd (former

Afribank)

Skye Bank Plc

Standard Chartered Bank Ltd Equatorial Trust Bank

Stanbic IBTC Bank Plc

Sterling Bank Plc

UBA Plc

Union Bank Plc

Unity Bank Plc

Wema Bank Plc

Zenith International Bank Plc

Source: Central Bank Nigeria (2005). Banking supervision annual report.

Central Bank Nigeria (2009). Annual report and statement of account.

Table 3. State of Nigerian Banking Sector from 2001- 2011

\begin{tabular}{llllllllllll}
\hline Category & 2001 & 2002 & 2003 & 2004 & 2005 & 2006 & 2007 & 2008 & 2009 & 2010 & 2011 \\
\hline & & & & & & & & & & & \\
Sound & 10 & 13 & 10 & 10 & 25 & 10 & 21 & 21 & 13 & 15 & 19 \\
Satisfactory & 63 & 54 & 53 & 51 & - & 5 & - & - & - & - & 1 \\
Marginal & 8 & 13 & 14 & 16 & - & 5 & 2 & 2 & 1 & 6 & \\
Unsound & 9 & 10 & 9 & 10 & - & 5 & 1 & 1 & 10 & 3 &
\end{tabular}

Source: Central Bank Nigeria (2004) Banking supervision annual report .

Nigeria Deposit Insurance Corporation (2006). Annual report and statement of accounts.

Nigeria Deposit Insurance Corporation (2006). Annual report and statement of accounts. 
Table 4. Operational Definition of Variables

\begin{tabular}{|c|c|c|c|c|}
\hline Variable & Code & Definition & $\begin{array}{c}\text { Expected } \\
\text { Effect }\end{array}$ & Source \\
\hline $\begin{array}{l}\text { Dependent Variable } \\
\text { Bank Performance } \\
\text { Return on Assets }\end{array}$ & BROA & $\begin{array}{l}\text { Profit after tax divided by } \\
\text { assets }\end{array}$ & & $\begin{array}{l}\text { Naceur, 2003; } \\
\text { Al-Tamimi, } 2008\end{array}$ \\
\hline $\begin{array}{l}\text { Independent Variables } \\
\text { Specific Bank } \\
\text { Capital Adequacy }\end{array}$ & BCAD & Equity divided by assets & $(+)$ & $\begin{array}{l}\text { Aburime,2009; } \\
\text { Flamini et al., } 2009 \\
\text { Olweny \& Shipho, } 2011\end{array}$ \\
\hline Operation Efficiency & BEFF & $\begin{array}{l}\text { Operating expenses divided } \\
\text { by operating income }\end{array}$ & $(+)$ & $\begin{array}{l}\text { Olweny \& Shipho, } 2011 \\
\text { Flamini et al, } 2009\end{array}$ \\
\hline Asset Quality & BASSQ & $\begin{array}{l}\text { Provision for bad loan } \\
\text { divided by gross loan }\end{array}$ & $(+)$ & $\begin{array}{l}\text { Flamini et al., } 2009 \\
\text { Olweny \& Shipho, } 2011\end{array}$ \\
\hline Liquidity & BLIQ & $\begin{array}{l}\text { Gross loan divided by } \\
\text { deposit }\end{array}$ & $(+)$ & Naceur, 2003; \\
\hline $\begin{array}{l}\text { Market Structure } \\
\text { Bank Concentration }\end{array}$ & $\mathrm{BCON}$ & $\begin{array}{l}\text { Percentage of assets of the } \\
\text { three largest banks to total } \\
\text { asset }\end{array}$ & $(+)$ & $\begin{array}{l}\text { Al-Tamimi, 2008; } \\
\text { Aburime, 2009; } \\
\text { Naceur, } 2003\end{array}$ \\
\hline $\begin{array}{l}\text { Macroeconomic } \\
\text { Gross Domestic Product }\end{array}$ & GDP & Growth in GDP & $(+)$ & $\begin{array}{l}\text { Al-Tamimi, 2008; Aburime, 2009; } \\
\text { Flamini et al., } 2009\end{array}$ \\
\hline Inflation & INFR & \multicolumn{2}{|c|}{$\begin{array}{l}\text { Percentage growth in overall }(+) \\
\text { price index of goods and } \\
\text { services. }\end{array}$} & Flamini et al., 2009 \\
\hline Intervening Variable & & & & \\
\hline Global Financial Condition & FINC & $\begin{array}{l}\text { Indicating variable with } \\
\text { value of }(0) \text { for the period } \\
\text { before global financial crisis } \\
\text { while the value of ( } 1 \text { ) for } \\
\text { during the crisis. }\end{array}$ & & \\
\hline
\end{tabular}


Table 5. Descriptive Statistics and Correlation Analysis

\begin{tabular}{|c|c|c|c|c|c|c|c|c|c|c|c|}
\hline Variable & $\mathrm{M}$ & D & BROA & $\mathrm{BCAD}$ & BOEFF & BASSQ & BLIQ & $\mathrm{BCON}$ & GDP & INFR & FINC \\
\hline BROA & 2.1 & 3.7 & 1.000 & & & & & & & & \\
\hline BCAD & 10.7 & 5.0 & -.232 & 1.000 & & & & & & & \\
\hline BOEFF & 62.7 & 15. & -.320 & -.456 & 1.000 & & & & & & \\
\hline BASSQ & 18.1 & 7.9 & $-.601^{*}$ & -.295 & .252 & 1.000 & & & & & \\
\hline BLIQ & 53.8 & 11.6 & .364 & -.032 & .126 & -.370 & 1.000 & & & & \\
\hline $\mathrm{BCON}$ & 27.7 & 4.4 & -.100 & .268 & .001 & -.444 & .496 & 1.000 & & & \\
\hline GDP & 5.9 & 2.3 & -.125 & .309 & -.184 & .061 & -.126 & -.256 & 1.000 & & \\
\hline INFR & 12.3 & 5.8 & .057 & -.349 & .127 & .432 & .103 & -.132 & .341 & 1.000 & \\
\hline FINC & .33 & .49 & -.288 & .389 & -.025 & -.223 & -.543 & -.055 & .307 & -.426 & 1.000 \\
\hline
\end{tabular}

Table 6. Regression Result for Model 1

\begin{tabular}{|c|c|c|c|}
\hline \multirow[t]{3}{*}{ Independent Variables } & Standardized & \multirow[t]{3}{*}{ t Statistic } & \multirow[t]{3}{*}{ Sig. } \\
\hline & Coefficients & & \\
\hline & Beta & & \\
\hline (Constant) & & 5.181 & $.007 * * *$ \\
\hline Capital Adequacy (BCAD) & -.252 & -1.374 & .241 \\
\hline Operating Efficiency (BOEFF) & -.352 & -2.381 & $.076^{*}$ \\
\hline Assets Quality (BASSQ) & -.902 & -5.191 & $.007 * *$ \\
\hline Liquidity (BLIQ) & .284 & 1.798 & .147 \\
\hline Concentration (BCON) & -.600 & -3.480 & $.025^{* *}$ \\
\hline Real Gross Domestic Product(GDP) & -.312 & -1.832 & .141 \\
\hline Inflation (INFR) & .400 & 2.206 & $.092 *$ \\
\hline $\mathrm{R}^{2}$ & & 0.939 & \\
\hline Adj $R^{2}$ & & 0.831 & $.027 * *$ \\
\hline F Ratio & & 8.731 & \\
\hline
\end{tabular}

$* * * 1 \%$ Significance, $* * 5 \%$ Significance and $* 10 \%$ Significance 
Table 7. Regression Result for Model 2

\begin{tabular}{|c|c|c|c|}
\hline \multirow[t]{3}{*}{ Independent Variables } & Standardized & \multirow[t]{3}{*}{ t Statistic } & \multirow[t]{3}{*}{ Sig. } \\
\hline & Coefficients & & \\
\hline & Beta & & \\
\hline (Constant) & & 4.354 & .022 \\
\hline Capital Adequacy (BCAD) & -.246 & -1.148 & .334 \\
\hline Operating Efficiency (BOEFF) & -.335 & -1.733 & .182 \\
\hline Assets Quality (BASSQ) & -.919 & -4.146 & $.025^{* *}$ \\
\hline Liquidity (BLIQ) & .248 & .914 & .428 \\
\hline Concentration (BCON) & -.591 & -2.894 & $.063^{*}$ \\
\hline Real Gross Domestic Product(GDP) & -.291 & -1.272 & .293 \\
\hline Inflation (INFR) & .384 & 1.684 & .191 \\
\hline Global Financial Crisis (FINC) & -.50 & -.176 & .872 \\
\hline $\mathrm{R}^{2}$ & & 0.939 & $.027 * *$ \\
\hline $\operatorname{Adj} R^{2}$ & & 0.777 & \\
\hline F Ratio & & 5.792 & $.88^{*}$ \\
\hline
\end{tabular}

$* * * 1 \%$ Significance, $* * 5 \%$ Significance and $* 10 \%$ Significance

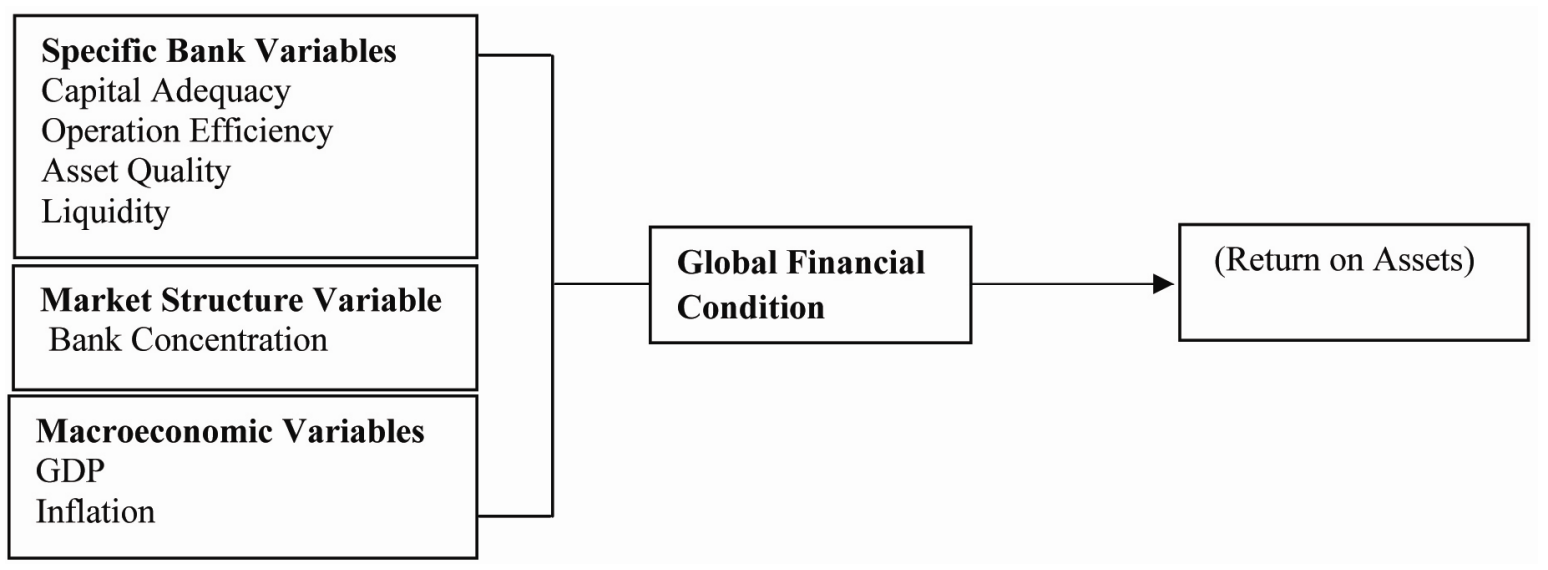

Figure 1. The Study Model 